\title{
EOSINOPHILIC ESOPHAGITIS: manometric and pHmetric findings
}

\author{
Monica Maria Cardoso MONNERAT and Eponina Maria de Oliveira LEMME
}

\begin{abstract}
Context - Eosinophilic esophagitis is an entity characterized by an esophageal inflammatory infiltrate of eosinophils, manifested by dysphagia, intermittent food impactions and symptoms similar to gastroesophageal reflux disease (GERD), that predominantly affects young adults. There may be association of eosinophilic esophagitis with GERD, and motor abnormalities have been described. Objective - The main objectives of this study are to describe the findings at esophageal manometry and $\mathrm{pH}$ monitoring in patients with eosinophilic esophagitis. Methods - Cross-sectional study of 20 patients with a diagnosis of eosinophilic esophagitis, submitted to esophageal manometry and $24 \mathrm{~h} \mathrm{pH}$ monitoring. Were analysed the manometric changes and the presence of abnormal reflux on pH monitoring. Results - Twenty patients ( 15 men, 5 women) had a mean age of 29 years. Motility disorders were found in $25 \%(5 / 20)$ patients with ineffective esophageal motility being the most common finding. $\mathrm{pH}$ monitoring revealed abnormal reflux on $25 \%$, without any relationship with manometric findings. Conclusions - Manometric abnormalities were observed in $25 \%$ of patients and abnormal reflux on $\mathrm{pH}$ monitoring also in $25 \%$. This study showed no relationship between abnormal reflux and the presence of manometric changes.
\end{abstract}

HEADINGS - Eosinophilic esophagitis. Esophageal motility disorders. Gastroesophageal reflux.

\section{INTRODUCTION}

Eosinophilic esophagitis (EoE) is a chronic, immune/antigen-mediated ${ }^{(5,13)}$ inflammatory esophageal disorder ${ }^{24,25)}$ with a rapidly increasing prevalence ${ }^{(6,17)}$. Recent epidemiologic data indicate that EoE is now the second leading cause of chronic esophagitis, behind gastroesophageal reflux disease $^{(20,26)}$ and a frequent cause of dysphagia ${ }^{(19)}$. Its prevalence in children ${ }^{(6)}$ and adults ${ }^{(20)}$ almost reaches levels comparable to Crohn's disease. EoE affects all age groups with a peak between the age of 20 and $50^{(4)}$. EoE is clinico-pathologically characterized by esophageal symptoms in combination with a dense esophageal eosinophilia, both being refractory to proton pump inhibitors. Notably, eosinophilic inflammation is absent in the stomach, small intestine and colon ${ }^{(9)}$.

EoE's leading symptom in adolescents and adults is dysphagia for solids with the imminent risk of prolonged food impactions $s^{(1,2,4,21)}$. Furthermore, patients frequently complain of retrosternal pain that is unrelated to swallowing activity ${ }^{(9)}$.

All studies agree that $80 \%-90 \%$ of patients have endoscopic features, most of them nonspecific ${ }^{(25,27)}$ and none of them are pathognomonic of $\operatorname{EoE}^{(5,13)}$. Sometimes the endoscopic patterns do not explain food impaction episodes, and in these cases a manometric study could be reasonable.
Lucendo et al. ${ }^{(14)}$ described manometric abnormalities in 26/30 (86,6\%) adult patients with EoE, and observed that the motor disorders exclusively affected the part of the esophagus comprising smooth muscle.

When the diagnosis of gastroesophageal reflux disease (GERD) vs EoE in not apparent despite endoscopy and biopsy, intraesophageal $\mathrm{pH}$ monitoring may be of use in excluding pathologic reflux as either the primary or a concomitant cause for esophageal eosinophilia, as recommended by the Consensus guidelines $^{(5,13)}$.

Some reports suggest that the interaction between GERD and EoE can be complex, and that the notion of establishing a clear distinction between the two disorders may be too simplistic. There are at least four situations in which GERD might be associated with esophageal eosinophils: (1) GERD causes esophageal injury that results in a mild eosinophilic infiltration; (2) GERD and EoE coexist but are unrelated; (3) EoE contributes to or causes GERD; or (4) GERD contributes to or causes EoE ${ }^{(14)}$.

The aim of this study was to evaluate the etiology of dysphagia and the presence of reflux in EoE, analyzing pHmetric and manometric disorders and if there was a correlation between them.

\section{METHODS}

This is a descriptive study of esophageal manometry 
and 24-hour $\mathrm{pH}$ monitoring in patients with eosinophilic esophagitis (EoE). The protocol of this research was approved by the Commission of Ethics in Research of Clementino Fraga Filho Hospital University, Federal University of Rio de Janeiro, RJ, Brazil. Cases were 20 symptomatic patients, recruited from the Gastroenterologic Division at Hospital University, based on previous clinical documentation of esophageal symptoms suggestive of EoE and current endoscopic biopsies with histopathology confirming EoE as defined by the Consensus guidelines ${ }^{(5,13)}$ and had at least 15 eosinophils/high power field. From 20 patients, 15 were man and 5 women, the average age was 29 years, with higher prevalence $(60 \%)$ between 15 and 30 years. The predominant symptoms were the recurrent food impaction $(55 \%)$, heartburn $(35 \%)$, dysphagia for solids $(25 \%)$ and thoracic pain $(15 \%)$, with average duration 34.6 months (3 months to 10 years). Every patient had been submitted to upper digestive endoscopy. All of them had endoscopic abnormalities, alone or combined. Noticeable loss of vascular pattern was found in all patients, with whitish plaques and longitudinal furrows. Patients received information about esophageal manometry and 24-hour $\mathrm{pH}$ monitoring exams and their possible side effects and complications. All subjects gave written informed consent.

\section{Manometric study}

Esophageal manometry (EM) was carried out at The Esophagus Unit of the University Hospital, using perfusion computerized equipment (ALACER, Brazil) and an 8-channel, 4,5 $\mathrm{mm}$ diameter polyvinyl catheter, with the patient in supine position and after the 6-hour fast. After administering topical anesthesia using lidocaine, the manometry tube was inserted trough the anesthetized nostril. A baseline gastric waveform was identified on the monitor screen to confirm placement of the four catheter sensing ports in the stomach after which an end-expiratory LES pressure in $\mathrm{mm} \mathrm{Hg}$ was obtained by the station pull trough method. The mean of the highest values recorded from each of the four ports was considered the LES pressure. Relaxation of the sphincter was evaluated after at least 10 wet swallows. After LES measurements, one of distal channels of the manometry catheter was positioned $3 \mathrm{~cm}$ above the LES upper border.

The esophageal body motility was measured by recording the response to at least 10 wet swallows of $3-5 \mathrm{~mL}$ volume. The manometry catheter was subsequently slowly withdrawn until the proximal hole of the catheter showed a good pressure waveform of the upper esophageal sphincter (UES) and relaxation of the UES pressure was monitored during the wet swallow. The catheter was further withdrawn until the second port recorded the UES pressure and after wet swallows the pharyngeal contraction and relaxation of the UES were recorded.

For diagnosing of motility abnormalities was used the International Classification of Esophageal Motor Disorders ${ }^{(22)}$ adapting where relevant, to the normal values employees in the Esophagus Unit from study ${ }^{(12)}$ in healthy volunteers (Table 1).
TABLE 1. Esophageal motility abnormalities (Spechler, Castell ${ }^{(22)}$ )

\begin{tabular}{ll}
\hline Motility abnormalities & Manometric findings \\
\hline $\begin{array}{l}\text { Ineffective esophageal } \\
\text { motility }\end{array}$ & $\begin{array}{c}\text { Number of low amplitude peristaltic } \\
\text { contractions }(<30 \mathrm{~mm} \mathrm{Hg}) \text { and/or } \\
\text { nontransmitted contractions }>20 \% \text { of } \\
\text { total number of wet swallows used for } \\
\text { esophageal body study }\end{array}$ \\
Hypotensive LES & LES pressure $<10 \mathrm{~mm} \mathrm{Hg}$ \\
Hypertensive LES & LES pressure $>32 \mathrm{~mm} \mathrm{Hg}^{(12)}$ \\
\hline
\end{tabular}

LES = lower esophageal sphincter

\section{4-hour pH ambulatory monitoring}

Twenty-four-hour intraesophageal $\mathrm{pH}$ studies were performed with portable digital recorders (MKIII, AL2 Alacer and Sigma SMP 2128, MG), an antimony catheter and an outer electrode. This test was performed after a 6-hour fast, introducing the catheter trough the nostril and placed 5 centimeters proximal to the LES (localized by manometric study) after calibrating the catheter for $\mathrm{pH} 1.07$ and 7.01 using reference solutions.

Patients continued their normal daily activities and were allowed a normal diet, with no citric fruits or soft drinks. Proton pump inhibitors (PPI) were discontinued at least 7 days prior to the examination and prokinetics agents 24 hours before the test.

It was considered reflux episode when the $\mathrm{pH}$ of the esophagus to fall to less than 4 for at least 15 seconds. For the interpretation of the results they hired the percentage $(\%)$ of total time $\mathrm{pH}<4$ and in the upright position and supine position; normal values as $\%$ total time $\leq 4.5 \%, \%$ upright time $\leq 7.0 \%$ and $\%$ supine time $\leq 2.5 \%{ }^{(8)}$.

\section{RESULTS}

\section{Esophageal manometry}

Esophageal manometry was normal in $75 \%$ of patients. Only five patients $(25 \%)$ presented manometric disturbances. The study of the upper esophageal sphincter was normal in all patients, including rest pressure, relaxation and pharyngoesophageal coordination. Motor disorders affect only the smooth muscles of esophagus. The LES was normal in 18 patients $(90 \%)$, hypertensive $(38.2 \mathrm{~mm} \mathrm{Hg})$ with normal relaxation in 1 patient $(5 \%)$ and excessive hypotensive $(4.6 \mathrm{~mm}$ $\mathrm{Hg}$ ) in another. The study of the esophageal body showed ineffective esophageal motility in 3 patients (15\%). Esophageal manometry results are presented in Table 2.

TABLE 2. Esophageal manometry results

\begin{tabular}{lc}
\hline Esophageal manometry results & $\mathbf{n}=\mathbf{2 0}(\%$ patients $)$ \\
\hline LES hypertensive & $1(5 \%)$ \\
LES hypotensive & $1(5 \%)$ \\
Ineffective esophageal motility & $3(15 \%)$ \\
Normal esophageal manometry & $15(75 \%)$ \\
Total & $20(100 \%)$ \\
\hline
\end{tabular}

LES = lower esophageal sphincter 


\section{4-hour pH monitoring}

PH monitoring was normal in $15 / 20$ patients $(75 \%)$ and revealed abnormal reflux in $5 / 20$ patients $(25 \%)$, being 3 patients with supine reflux and 2 with bipositional reflux. One patient presented bronchospasm coincident with reflux (index of symptoms positive). Table 3 shows the findings described.

The five patients with abnormal reflux on $\mathrm{pH}$ monitoring received double dose PPI during 8 weeks and then the esophageal biopsies were repeated. There was persistence of the endoscopic findings of EoE and the esophageal eosinophilia.

TABLE 3. $\mathrm{pH}$ monitoring results

\begin{tabular}{lc}
\hline $\mathrm{pH}$ monitoring results & $\mathrm{n}=20(\%$ patients $)$ \\
\hline Normal $\mathrm{pH}$ monitoring & $15(75 \%)$ \\
Abnormal bipositional & $2(10 \%)$ \\
Abnormal supine & $3(15 \%)$ \\
\hline
\end{tabular}

\section{Correlation between $\mathrm{pH}$ monitoring and manometry findings}

There was no correlation between manometry and $\mathrm{pH}$ monitoring findings.

From five patients with abnormal reflux only one presented abnormal manometry ineffective esophageal motility and from five patients with abnormal manometry only one had abnormal reflux (Tables 4 and 5).

TABLE 4. Abnormal $\mathrm{pH}$ monitoring $\mathrm{x}$ esophageal manometry

\begin{tabular}{lcc}
\hline Patient & Abnormal reflux & EM \\
\hline R.K. & Bipositional & Normal \\
A.G. & Bipositional & Normal \\
D.S.S. & Supine & IEM \\
L.R.R. & Supine & Normal \\
F.D.S. & Supine & Normal \\
\hline
\end{tabular}

EM = esophageal manometry

IEM = ineffective esophageal motility

TABLE 5. Abnormal esophageal manometry x pH monitoring

\begin{tabular}{lcc}
\hline Patient & Abnormal EM & $\mathrm{pH}$ monitoring \\
\hline E.R.M. & Hypertensive LES & Normal \\
A.E. & Excessive hypotensive LES pressure & Normal \\
D.S.S. & IEM & Abnormal supine \\
R.A. & IEM & Normal \\
J.R.S.L. & IEM & Normal \\
\hline
\end{tabular}

EM = esophageal manometry

LES = lower esophageal sphincter

IEM = ineffective esophageal motility

\section{DISCUSSION}

Esophageal motility has not been well characterized in patients who have EoE. NurKo et al. ${ }^{(18)}$ published, in 2008, a literature review on esophageal dismotility in EoE and identified 19 studies in adults, with a total of 115 patients.
Primary disorders were found in 12 patients: 2 with achalasia, diffuse esophageal spasm in 7 and nutcracker esophagus in 3 patients. LES was normal in 100 patients, hypotensive in 12 , hypertensive in 3 and incomplete relaxation was found in 2 achalasia patients. Unspecific motor abnormalities (tertiary contractions, low-amplitude and ineffective esophageal motility were reported in 35 patients $(34.3 \%)$ and contractions of high amplitude in 11. Therefore, manometric disturbances were found in $41 \%$ of patients.

In our study, esophageal manometry was normal in 15 patients $(75 \%)$. Esophageal manometry was abnormal in 5 patients in this study $(25 \%)$, being the most frequent change ineffective esophageal motility, identified in 3 patients. We also found a patient with hypotensive LES $(4.5 \mathrm{~mm} \mathrm{Hg})$ and another with hypertensive LES $(38.2 \mathrm{~mm} \mathrm{Hg})$. The upper esophageal sphincter was normal in all patients. In our study, only one patient who presented manometric change had abnormal reflux. Motility disorders were present in $40 \%$ $(2 / 5)$ of patients with dysphagia for solids and 36\% (4/11) of patients with recurrent food impaction.

Normal $\mathrm{pH}$ monitoring was found in patient who presented hypotensive lower esophageal sphincter.

According to Korsapati et al. ${ }^{(10)}$ esophageal manometry measures only the circular muscle function of the esophagus, and not all motility disorders are discovered by this method.

Martin et al. ${ }^{(15)}$ reported normal LES in 9 patients ( $81 \%$ ), hypotensive in $2(18 \%)$, and ineffective esophageal motility was identified in 5 patients $(45 \%)$, a percentage greater than the one described by other authors.

Lucendo et al. ${ }^{(14)}$ described manometric abnormalities in $26 / 30(86,6 \%)$ adult patients with EoE, and observed that the motor disorders exclusively affected the part of the esophagus comprising smooth muscle. The manometric study of the upper esophageal sphincter was normal in all patients, including resting pressure, dynamic behavior, and pharyngoesophageal motor coordination. The LES was hypotensive in $12 / 30(40 \%)$, a hypoperistaltic motor pattern was found in $17 / 30$ patients $(56.7 \%)$, and a hyperkinetic pattern in 9 patients $(30 \%)$.

Hejazi et al. ${ }^{(7)}$ inferred that dysphagia in EoE can be attributed at least in part to motility disorders that can improves with treatment. Some authors suggest that there are different phases in the development of motor abnormalities, similarly to what happens in other disorders affecting esophageal function such as GERD and achalasia. Initially the motility is normal, then it would raise spastic hypercontractility and diffuse esophageal spasm that evolutes to simultaneous low-amplitude contractions.

Rothenberg et al. ${ }^{(21)}$ analysed the results of nine studies on esophageal $\mathrm{pH}$ monitoring in EoE, and abnormal results were found in $18 \%$ of 100 patients. In the publication of Martin et al. ${ }^{(15)}$ abnormal reflux on $\mathrm{pH}$ monitoring was found in two patients $(18 \%)$.

GERD is a common condition and may affect $10 \%$ to $20 \%$ of healthy adults ${ }^{(3)}$, while the EoE can affect up to $1 \%$ of a population ${ }^{(20)}$. So, GERD and EoE coexist but are unrelated ${ }^{(16,23)}$. 
In our study, the presence of abnormal reflux in five patients $(25 \%)$, attach to overlap between EoE and GERD. The five patients with abnormal reflux on $\mathrm{pH}$ monitoring received double dosage PPI during 8 weeks and then the esophageal biopsies were repeated. There was not remission of dysphagia, neither the endoscopic findings of EoE and the esophageal eosinophilia. This way, GERD was discarded as a cause of esophageal eosinophilia, as this continued after PPI treatment.

In 2007, Consensus guidelines ${ }^{(5)}$, one of the diagnostic criteria for EoE is that there would be no improvement with esophageal eosinophilia with acid suppression. However, in a high percentage adult patients with eosinophilic infiltration in the esophagus present coexisting GERD ${ }^{(16)}$. This ratifies that the partial response to PPI does not exclude EoE diagnosis, and that $\mathrm{pH}$ monitoring and esophageal manometry should be performed in patients with atypical symptoms or when there is no diagnostic definition. It is important to emphasize that EoE can coexist with GERD; however, treatment with PPI allows control of acid reflux but does not improves the dysphagia.

Another possible association between EoE and GERD is that eosinophils secret potent agents that can affect esophageal smooth muscle and nerve function. Cytotoxic effects of eosinophils may render esophageal epithelium more susceptible to reflux injury ${ }^{(23)}$.
We find in our study $5 / 20(25 \%)$ patients who presented manometric abnormalities (hypertensive LES in 1 patient, excessive hypotensive LES in other and IEM in 3 patients). Only 1 patient with ineffective esophageal motility had abnormal reflux on $\mathrm{pH}$ (supine position).

IEM was the most frequent manometric abnormality in this study, as in other publications about $\operatorname{EoE}^{(7,15,18)}$. IEM has been associated with reflux in both the supine and upright position, prolonged esophageal clearance, and delayed of bolus transport ${ }^{(11)}$.

Five patients $(25 \%)$ showed pathological reflux on $\mathrm{pH}$ monitoring (two patients with bipositional reflux and three patients with supine reflux). One of these patients presented IEM on manometry. The presence of abnormal reflux in the other patients would be related to overlap between EoE and GERD. Our study may have some limitations for the analysis pHmetric and manometric features arising from the small number of patients with EoE, but there was no correlation between $\mathrm{pHmetric}$ and manometric findings.

In conclusion, manometric abnormalities were observed in $25 \%$ of patients and abnormal reflux on $\mathrm{pH}$ monitoring also in $25 \%$. Ineffective esophageal motility was the most frequent disorder in this study. There was no relationship between abnormal reflux and the presence of manometric changes in these patients.

Monnerat MMC, Lemme EMO. Esofagite eosinofílica: achados manométricos e pHmétricos. Arq Gastroenterol. 2012;49(2):113-7.

RESUMO - Contexto - A esofagite eosinofílica é uma doença inflamatória crônica, caracterizada por infiltrado eosinofílico no esôfago e se manifesta por disfagia, impactações alimentares e sintomas similares aos da doença do refluxo gastroesofágico (DRGE), com maior incidência em adultos jovens. Pode haver associação da esofagite eosinofílica com a DRGE, e anormalidades motoras têm sido descritas. Objetivo - Os principais objetivos deste estudo são descrever as alterações manométricas e a presença de refluxo anormal à pHmetria esofágica em pacientes com esofagite eosinofílica. Métodos - Estudo transversal de 20 pacientes com diagnóstico de esofagite eosinofílica, submetidos a esofagomanometria e pHmetria esofagiana de $24 \mathrm{~h}$. Foram analisadas as alterações manométricas e a presença de refluxo anormal à pHmetria. Resultados - Vinte pacientes (15 homens, 5 mulheres) com média de idade de 29 anos. Distúrbios da motilidade esofagiana foram encontrados em $25 \%$ dos pacientes, com predomínio da motilidade esofagiana ineficaz. A pHmetria revelou refluxo anormal também em $25 \%$, sem relação entre os achados manométricos e pHmétricos. Conclusões Anormalidades manométricas foram encontradas em $25 \%$ dos pacientes e refluxo anormal à pHmetria também em $25 \%$. Neste estudo, não houve relação entre refluxo anormal e a presença de alterações à esofagomanometria.

DESCRITORES - Esofagite eosinofílica. Transtornos da motilidade esofágica. Refluxo gastroesofágico. 


\section{REFERENCES}

1. Arora AS, Yamazaki K. Eosinophilic esophagitis: asthma of the esophagus? Clin Gastroenterol Hepatol. 2004;2:523-30.

2. Attwood SE, Smyrk TC, Demeester TR, Jones JB. Esophageal eosinophilia with dysphagia: a distinct clinicopathologic syndrome. Dig Dis Sci. 1993;38:109-16.

3. Dent J, El Serag-HB, Wallander MA, Johansson S. Epidemiology of gastroesophageal reflux reflux disease: a systematic review. Gut. 2005;54:710-7.

4. Desai TK, Stecevic V, Chang CH, Goldstein NS, Badizadegan K, Furuta GT Association of eosinophilic inflammation with esophageal food impaction in adults. Gastrointest Endosc. 2005;61:795-801.

5. Furuta GT, Liacouras C, Collins MH, Gupta SK, Justinich C, Putnam PE, Bonis P, Hassall E, Straumann A, Rothemberg ME. Eosinophilic esophagitis in children and adults: a systematic review and consensus recommendations for diagnosis and treatment. Gastroenterology. 2007;133:1342-63.

6. Gupta SK, Fitzgerald JF, Kondratyuk T, HogenEsch H. Cytokine expression in normal and inflamed esophageal mucosa: a study into the pathogenesis of allergic eosinophilic esophagitis. J Pediatr Gastroenterol Nutr. 2006;42:22-6.

7. Hejazi RA, Reddymasu SC, Sostarich S, McCallum RW. Disturbances of esophageal motility in eosinophilic esophagitis: a case series. Dysphagia. 2010;25:231-7.

8. Johnson LF, DeMeester TR. Twenty-four hour $\mathrm{pH}$ monitoring of the distal esophagus. A quantitative measure of gastroesophageal reflux. Am J Gastroenterol. 1974;62:325-32

9. Kapel RC, Miller JK, Torres C, Aksoy S, Lash R, Katzka DA. Eosinophilic esophagitis: a prevalent disease in the United States that affects all age groups. Gastroenterology. 2008;134:1316-21.

10. Korsapati H, Babaei A, Bhargava V, Dohil R, Quin A, Mittal RK. Dysfunction of the longitudinal muscles of the esophagus in eosinophilic esophagitis. Gut. 2009;58:1056-62.

11. Lemme EM, Abrahão Jr, LJ, Manhães Y, Schechter R, Carvalho BB, Alvariz A. Ineffective esophageal motility in gastroesophageal erosive reflux disease and in nonerosive reflux disease. Are They Different? J Clin Gastroenterol. 2005;39:224-7.

12. Lemme EMO, Domingues GR, Silva LFD, Firman CG, Pantoja JAS. Esophageal manometry: preliminary values in health adult volunteers. Gastroenterol Endosc Dig. 2001;24:29-35.

13. Liacouras CA, Furuta GT, Hirano I, Atkins D, Attwood SE, Bonis PA, Burks AW, Chehade M, Collins MH, Dellon ES, Dohil R, Falk GW, Gonsalves N, Gupta SK, Katzka DA, Lucendo AJ, Markowitz JE, Noel RJ, Odze RD, Putnam PE, Richter JE, Romero Y, Ruchelli E, Sampson HA, Schoepfer A, Shaheen NJ, Sicherer SH, Spechler S, Spergel JM, Straumann A, Wershil BK, Rothenberg ME, Aceves SS. Eosinophilic esophagitis: updated consensus recommendations for children and adults. J Allergy Clin Immunol. 2011;128:3-20.e6
14. Lucendo AJ, Pascual-Turrión JM, Navarro M, Comas C, Castillo P, Letrán A, Caballero MT, Larrauri J. Endoscopic, bioptic, and manometric findings in eosinophilic esophagitis before and after steroid therapy: a case series. Endoscopy 2007;39:765-71.

15. Martin LM, Vaquero CS, Prudencio SS, Perona JC, Gisbert JP, Otero, RM. Eosinophilic esophagitis in adult - clinical, endoscopic, $\mathrm{pH}$-metric, and manometric findings. Rev Esp Enferm Dig. 2008;100:476-80.

16. Molina Infante J, Fernando-Qoqiauri L, Mateos-Rodriguez JM, Pérez-Gallardo B, Prieto-Bermejo AB. Overlap of reflux and eosinophilic esophagitis in two patients requiring different therapies: a review of the literature. World J Gastroenterol. 2008;14:1463-6.

17. Noel RJ, Putnam PE, Rothenberg ME. Eosinophilic esophagitis. N Engl J Med. 2004;351:940-1.

18. NurKo S, Rosen R. Esophageal dysmotility in patients who have eosinophilic Esophagitis.. Gastrointest Clin N Am. 2008;18:73-89.

19. Portmann S, Heer P, Bussmann Ch. Epidemiology of eosinophilic esophagitis: data from a community-based longitudinal study [abstract]. Gastroenterology. 2007;132:A-609.

20. Ronkainen J, Talley NJ, Aro P, Storskrubb T, Johansson SE, Lind T, BollingSternevald E, Vieth M, Stolte M, Walker MM, Agréus L. Prevalence of esophagea eosinophils and eosinophilic esophagitis in adults: the population-based Kalixanda study. Gut. 2007;56:615-20.

21. Rothenberg ME, Mishra A, Collins MH, Putnam PE. Pathogenesis and clinica features of eosinophilic esophagitis. J Allergy Clin Immunol. 2001;108:891-4.

22. Spechler SJ, Castell DO. Classification of oesophageal motility abnormalities. Gut. 2001;49:145-51

23. Spechler SJ, Genta R, Souza R. Thougts on the complex relationship between gastroesophageal reflux reflux disease and eosinophilic esophagitis. Am J Gastroenterol. 2007;102:1301-4.

24. Straumann A, Bauer M, Fischer B, Blaser K, Simon HU. Idiopathic eosinophilic esophagitis is associated with a Th2-type allergic inflammatory response. J Allergy Clin Immunol. 2001;108:954-61.

25. Straumann A, Spichtin HP, Grize L, Bucher KA, Beglinger C, Simon H-U. Natural history of primary eosinophilic esophagitis: a follow-up of 30 adult patients for up to 11.5 years. Gastroenterology. 2003;125:1660-9.

26. Straumann A, Simon HU. Eosinophilic esophagitis: escalating epidemiology? J Allergy Clin Immunol. 2005;115:418-9.

27. Yan BM, Schaffer EA. Eosinophilic esophagitis: a newly established cause of dysphagia. World J Gastroenterol. 2006;12:2328-34. 